White-hot technology lives on in France

New minister

\section{plans great}

\section{leap forward}

\section{Paris, June}

Part of the mystique of the new Socialist government in France is its almost religious attitude to science, which has startled those on the left who are habitually critical of modern technology. Thus the left-wing daily Libération last week described the Minister of State for Science, Jean-Pierre Chevènement, as a man who embraced growth for growth's sake and sought Soviet-style state control of science. There was no room in Chevènement's policies, said Libération, for the ecological movement or for the debureaucratization, demilitarization and democratization of science.

This is in part true and part false. Chevènement has lost no time in gathering his powers but he is also calling for greater democracy in science planning going beyond the "democracy of the party faithful". He wants science to be "opened up", but chiefly towards industry. And he is not much interested in the environmentalists. On energy policy he is strongly pro-nuclear. And he will have no control of military science, which absorbs 37 per cent of a total French research and development grant of 50,000 million French francs ( $£ 5,000$ million).

Chevènement sees science rather in the terms of $\mathrm{Mr}$ Harold Wilson's British government of 1964. It is the white heat of the technological revolution in which to forge socialism. Science has an "ethical value", he says, in that "there is no socialism without research". He includes in the term "research" most forms of new knowledge - such as social science, which may see a resurgence.

Science in the new government will be expected to help raise the French Gross National Product, to pay for the reconstruction of French society that the Socialist Party has in mind. Some think that an annual growth of 3-4 per cent of the GNP will be needed, compared with 0-1 per cent at present, whence Chevènement's interest in links between science and industry.

During the interregnum, Chevènement battled for weeks with Pierre Joxe, then Minister of Industry, for control of certain key agencies. In the end he appears to have won, although the relevant decree is not yet signed. Joxe has left the government to head the Socialist Party in the new assembly, and the promised decree should give Chevènement the powers he wants.

Specifically, he wants full control of the

Centre National de la Recherche Scientifique (CNRS), the principal body supporting basic science (including social science and humanities) in France; of the Agence Nationale pour la Valorisation de la Recherche (ANVAR), which primes the innovation pump by seeking ideas in universities and government laboratories and supporting their development in industry; of the Mission Interministerielle pour l'Information Scientifique et Technique (MIDIST), an interministerial agency which seeks to improve the national flow of information on science and technology; and of the Délégation Générale à la Recherche Scientifique et Technique (DGRST), which will perform as his administration.

Chevènement (subject to the decree) has also won power over other research agencies which will remain nominally within their present ministries. He will be in control of their budgets, which gives him effective power over their work but not their appointments - a formula he proposed to save ruffled feathers at the ministries he was plundering. These are the Commissariat à l'Energie Atomique (nonmilitary work only), the Centre National d'Etudes Spatiales and the agricultural, medical, ocean science and overseas development research councils. In total,

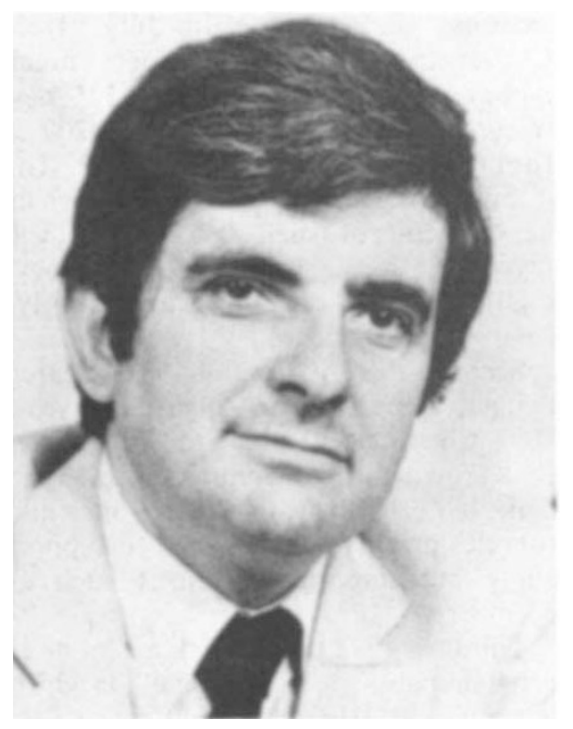

Chevènement, ready to go

Chevènement will control directly a budget approaching FF 20,000 million.

If the government can hold to its election promises, this budget should rise by some 10 per cent a year until 1985; and by means of low interest loans to industry for research and development projects, the FF 30,000 million industrial sector is planned to rise at the same rate.

For the moment, Chevènement -

\title{
Universities jeopardize German budget
}

A row in West Germany over the funding of new university buildings culminated last week in the rejection of the entire federal budget for 1981. The Bundesrat, the upper chamber of the parliament whose members are the presidents of the eleven Länder, threw out the budget approved on 6 June by the Bundestag, the lower house, on the grounds that it makes insufficient provision for new construction in universities. It was the first time since 1963 that the Bundesrat has overruled the Bundestag-approved budget.

The majority of Länder governments claim that by allocating only DM 680 million for university construction in 1981, compared with the DM 850 million originally planned, the federal government is reneging on its constitutional obligation to meet half of the costs with the Länder. The Bundesrat says that the reduced sum is not enough to pay for projects already under way, let alone for embarking on new ones. Herr Albrecht, president of the Bundesrat, is said to believe that a figure nearer DM 1,300 million is needed if the universities are to expand to meet rising demand. So great is the sense of grievance of the Länder governments that they are claiming that the Bundestag has violated a basic constitutional law - which states that the costs of construction should be shared equally between the Länder and the federal government - and they are taking their case to the constitutional court.

The matter has also been referred to an arbitration committee which is due to meet next week. An earlier attempt at compromise, which would have guaranteed the Länder reimbursement after 1984 for extra money spent in 1981, failed. But it is now hoped that the Länder will agree to accept reimbursement of DM 120 million in 1982 and the remaining DM 50 million in 1983.

Until this year, cuts in the West German federal budget were practically unheard of But the worsening economy has forced the government to look for savings. The Länder have used the constitutional obligation on university construction funds to challenge the government's plans for savings and are said to favour cuts in agencies with large bureaucracies such as those dealing with employment and social security.

West Germany has been expanding its universities since the early 1970 s and has already spent DM 25,000 million, mainly on upgrading technical colleges to university status. The plan is to invest another DM 20,000 million if the economy can stand it.

The recurrent grant to universities, which is paid by the local Länder governments, is not involved in the dispute.

Judy Redfearn 
assuming the decree is forthcoming - has three targets.

First, there is an adjustment to the 1981 national budget, due in July. Here Chevènement does not expect much money, but he has promised 525 new research jobs among his agencies, 200 of them for scientists (the rest for technicians). In the agencies over which he has full control (such as CNRS) he will favour the social sciences, basic biology, medical sciences and (surprisingly) environmental science.

Second, there is the full 1982 research budget, to be fixed in August this year. Here Chevènement plans the full 10 per cent growth, in real terms, and plans to make biotechnology, microelectronics and robotics priority subjects, and to support ailing but important subjects such as chemistry.

Third, in 1982 he will seek a "loi de la programmation de la recherche", in which the National Assembly would vote a firm five-year plan and budget within which his ministry could operate without fear of political setback year to year. Such a "loi programme" has not been tried before outside defence, and it will be a supreme test of Chevènement's undoubted political powers to get such a law approved.

To that end, he is calling a national colloquium of scientists and others interested in science policy for December this year, to thrash out a "new politics"' for science and rally support. Robert Walgate

\section{US science research \\ Keyworth reassures}

\section{Washington}

In his first public appearance since being nominated as President Reagan's Science Advisor and director of the Office of Science and Technology Policy, Dr George A. Keyworth II said last week that the new Administration "views basic research as a vital investment with a good return", that it would seek to increase industry's involvement in research and development and that greater international collaboration was essential in such capital-intensive fields as high-energy physics and space research.

On a less positive note, he warned that the United States could no longer expect to dominate research in all scientific disciplines and should accept that "our country has relinquished its pre-eminence in some scientific fields"'. He also stressed that support for research should be aimed primarily at those areas considered important for industrial, military or other essential technologies, or where efforts were proving particularly productive, such as computer science and genetic engineering.

Dr Keyworth's remarks were made in a speech to a meeting organized by the American Association for the Advancement of Science (AAAS) to discuss recent trends in the federal research and develop- ment budget. Many of those present were impressed that although Dr Keyworth, a 41-year-old nuclear physicist who has spent most of his career at the Los Alamos Scientific Laboratory, has virtually no experience of Washington science policy circles, his remarks demonstrated a grasp of many of the issues facing the Administration.

Asked about attempts by the Office of Management and Budget to apply strict cost-accounting procedures to university scientists, for example, Dr Keyworth replied that he himself had never been required to punch a time-clock, but that there were arguments about public accountability that needed to be closely considered. He also expressed concern at the possible damage to international relationships that might follow budget-based decisions to withdraw from projects such as the International Solar Polar Mission, being planned jointly with the European Space Agency.

In his speech, Dr Keyworth emphasized that he saw his role as an "objective adviser" in the White House rather than an inside lobbyist for the engineering and scientific communities. "The Science Advisor in this Administration perhaps more than in any other will be an important member of a team of domestic and international advisers", he added.

The content of his speech made it clear that Dr Keyworth is likely to pursue many of the same goals as his predecessor, Dr Frank Press. Referring to the need to reduce the burden of "unnecessary" regulation on the private sector, he said that the Office of Science and Technology Policy would continue to work closely with others in the Administration to strengthen the scientific foundation of federal regulatory decision-making.

However, Dr Keyworth, who has been closely involved in nuclear weapons research at Los Alamos, said he believes that "our country's military might should be second to none", and has also been reported as saying that within the new Administration "science and engineering that support the development of a stronger defence have top priority."

In previous administrations such remarks might have been taken as a warning signal by the biomedical research community. But the commercial potential of genetic engineering, being a rapidly expanding field of high technology, seems to have kept such research in favour. "In general, I think we will see continued strong support for the biological and biomedical sciences", Dr Keyworth said.

Other speakers from the Administration who addressed the AAAS meeting supported the contention that basic science had little to fear from Mr Reagan, and that cuts in the research and development budget were intended to fall primarily in those areas where private industry might shoulder responsibility.

Many of those attending the conference, however, were not totally convinced. Several questions were raised about the Administration's proposal to eliminate science education programmes at the National Science Foundation (some of which appear to have been salvaged by Congress). Others, such as Dr Ronald W. Lamont-Havers, director of research policy at the Massachusetts General Hospital, expressed concern that even though the Administration might believe in the need to support scientific excellence, budget constraints on research funding were likely to result in high-quality research not receiving adequate federal backing.

David Dickson

\section{EEC university qualifications}

\section{Degree of agreement}

\section{Brussels}

Education ministers from the European Community's ten member states, meeting in Luxembourg in June, considered the tricky problem of improving the mutual recognition of diplomas and periods of study undertaken at higher education institutes.

In theory the principle of the freedom of employment set out in the Treaty of Rome should guarantee that a qualification gained in one member state should open the same economic doors in another state, but this is far from being the case. As one example, a teacher with a degree from the University of Lille who spent her working life in Belgium was not granted her full pension rights because the Belgian state did not recognize her qualification.

No one has been foolhardy enough this time to suggest establishing a Euro-degree on the lines of the much-maligned Euroloaf or Euro-beer. The low-key approach adopted by the European Commission is to improve the availability of information. EURYDICE, the European information network on education which became operational last year, would link up with national units to provide information in five key areas - entry requirements for first degrees, transfer without loss of acquired rights from a course started in one country to a similar course in another member country, requirements for postgraduate studies or research in another member state, finding work in a member state with qualifications obtained in another, and details of career development.

The Education Council has approved these ideas and the Commission has until March 1982, when the education ministers meet again, to put forward some precise ideas on implementing the scheme.

But this leaves the crucial problem untouched. Should the Community risk an outcry from the academic world by forcing universities to accredit each others' degrees with the same value and worth? Desirable though that would be as a means of increasing the mobility of European 